\title{
The role of internal auditing to support in maintaining corporate governance preference
}

\author{
An Applied Study on Private Banks in Iraq
}

\section{Dlshad mohammedsaleh yousif}

Paitaxt technical private institute

\section{ARTICLE INFO}

Article History:

Received: 4/11/2019

Accepted: 18/12/2019

Published: Fall /2019

DOI:

10.25212/lfu.qzj.4.4.43

\section{Keywords:}

Corporate Governance, Internal Auditor,

Responsibility

\begin{abstract}
The technological and scientific progress that accompanied this era led to an increase in the number and size of economic organizations, and thus an increase in the responsibilities assigned to these organizations to implement their goals. Moreover, the complexity of administrative problems resulting from the practice of various activities makes internal audit an urgent need imposed by the nature of modern scientific management to preserve the financial resources provided to these organizations. The success that the organization aims for depends on the fertile environment and the dialectical relationship between the individual's success and the organization's success. When the organization is part of the indeterminacy, success is the mutual benefit of both the organization and the differentiation depending on the hegemony of the inferior system and the justice between the individuals. The concept of organizational nanny succeeds in developing the relationship between the founders and investing in markets and other investors because of its clear importance to the economic situation of public and private participating organizations and society in general.
\end{abstract}

Financial crises led to the press, justice, and the American financial community to search for the vital role of administrative boards, audit committees, senior management, and external and internal auditors in organizational organization processes. All this participation in one way or another in the organizational possession by emphasizing the efficiency of operations, following and obeying the rules and regulations that demonstrate 
confidence in financial reports, caring for the financial position of organizations and maintaining an acceptable level of risk if they their duties properly.

In light of the aforementioned, in addition to supporting the nanny in the organizations, strengthening the guidance, management and control systems will achieve or implement the goals of the organization automatically without any interference or effects to maintain the treatment control between the organizations all the relevant individuals. Therefore, the researcher will focus on the role and function of the internal audit and its effects on the organizational governance process in order to support it in response to the interests of the various parties in society, the public and private sectors.

\section{Introduction:}

The scientific and technological progress that accompanied this era has led to an increase in the numbers and sizes of companies of all kinds and an increase in the responsibilities incumbent on them for the purpose of achieving their desired goals, in addition to the complexity of the administrative problems resulting from their practice of various activities, which made internal audit imperative required by the nature of scientific management Modern to preserve the financial resources available to them, the success that companies seek is based on the fertile environment and the dialectical relationship between the individual and the company, when the company becomes part of the individual, its success benefits the individual and this is achieved by Adoption of the rule of law, order and justice among individuals, and on this basis of institutional control as a concept has succeeded in developing and improving the relationship between the founders and investors and capital markets, and others because of the obvious importance of the economic situation of public companies, private and society in general.

And by institutional control, companies are directed and monitored and the necessary structure is defined for the distribution of duties and responsibilities among shareholders in the company such as the board of directors, managers and other stakeholders, as well as setting rules and provisions to take the necessary decisions for the shareholding company's affairs, and therefore institutional control gives the appropriate structure in which the company can lay down Its goals and the means to achieve it and work to properly monitor its performance. 
These financial scandals have prompted the press, Congress, the judiciary, and the American financial community to search for the vital role of boards of directors, audit committees, senior management, and internal and external auditors in institutional control operations, as all of these parties participate in institutional control by confirming the efficiency of operations, compliance with laws and regulations, and a statement of confidence in Financial reports and sponsoring the company's financial position and maintaining an acceptable level of risk if they carry out their duties truly.

Accordingly, the researcher will focus on the role of the internal audit function in directing the companies 'operations towards success as it helps in examining and evaluating financial, administrative and operational activities and providing management personnel at all levels with the information necessary to help achieve physical protection of the assets and operations that fall under their responsibility and that is one of the controls Institutional as a department that works to control work within companies, especially when the shareholder base expands and begins to separate ownership and management and the necessity of adopting international standards for institutional control of different types and areas of their activities (commercial, industrial and service companies and Banks and financial institutions).

In the light of the foregoing, strengthening institutional control in companies and strengthening the guidance, management and control system will achieve the company's goals without influence or interference from any party until there is finally a fair deal between the company and all parties involved with it.

Literature review: Through the presentation of the study (Catherine \& Sullivan) in which he clarified instilling institutional control in developing, emerging and transitional economies, there is a need to establish a system of institutional control based on rules and provisions (rather than based on relationships) to combat underlying interests, dismantle the hierarchical ownership structure that allows entrants By controlling and sometimes plundering assets from publicly owned companies that are based on a very small amount of direct ownership, and consequently have minimal effects, so isolating policy from the decision-making process and creating buffer walls between the government and management in joint-stock companies in which the state is What in control where you see the researcher said the study focused on the disarmament of power and control of the parties have the right to decide which affects small shareholders and new investors and thus lead to the collapse of those companies and weaken its financial position has shown 
how important it is to control the institutional in the development of rules and provisions that limit it.

Therefore study (Nestor) on the international convergence in the field of institutional control, it is noted that it indicates that companies all over the world have begun to realize the value of corporate control and have begun to build their knowledge of global best practices for those in charge of corporate matters and it is up to the investors to ask for better control and realize what they mean They give it the value it deserves worldwide, bypassing stereotypes and over-simplification.

Through a presentation of the study (Hessel) in which he explained the role of corporate boards: oversight through representation that gave an idea of the American model and the German model, they both reflect fundamental differences in terms of large ownership of individuals in the United States, versus focused ownership and the ownership of vast companies in Germany And the perspective of private interests in the market economy in the United States in exchange for directing the social economy in Germany, relying on external oversight of the company's performance in the United States in exchange for relying on internal mechanisms in Germany. Many of the countries that are close to them have adopted these two models as criteria for the control systems of "external parties" and "internal parties".

As for the study (Ira M. Millstein) on the role of boards of directors and shareholders in institutional control, the researcher believes that this study showed that institutional control aims to improve the performance of companies and ensure that they obtain capital at a reasonable cost to achieve growth and development, in addition to achieving the best competitive performance the company can It achieves in its economic environment.

While a study (Gregory \& Lilien) on the role of the audit committee in institutional control clarified how the audit committee supervises internal and external auditors and in giving assurance about the safety and reliability of operations and thus raising the efficiency and quality of financial reports and this as a result is due to the company continuous improvement and adding value to it And to the shareholders.

By going to (Ramamoorti) study on internal auditing, history, development, and capabilities, it gave an idea about the beginning of the emergence of internal auditing to the 
latest developments that took place on the profession as this study was used for the requirements of the third chapter, the paragraph of the historical development of the internal audit profession, and the researcher added that the reason Behind this development was to keep pace with developments in the environment and the problems that led to the emergence of the phenomenon of institutional control, which led to the results of the changes that the internal audit profession has achieved.

(William) was a study on internal audit and risk assessment and management processes where when planning to monitor risks and threats they must assess the level of each risk or threat and thus determine any appropriate controls to mitigate risks as well as determine the level of experience required as it focused on self-assessment of risks and notes from this study that One of the new internal audit tasks is to focus on risk management and the researcher benefited from this theoretical study and the researcher added to it how the process of identifying and assessing risks has become one of the necessary tasks for the internal auditor as this was identified within the standards of internal audit and pal The result affects support and strengthening of institutional control

Finally, a study (Matyjewicz and Blackburn) came about the need for institutional control: to avoid the crashes that ravaged the world of money and business, organizations, societies and committees began to develop appropriate solutions to reduce this phenomenon and the result is the emergence of institutional control.

On this basis, the researcher decided to address the concept of institutional control from its relationship to the function of internal audit because it has a significant and important impact in promoting this concept and support it because internal audit is the first basis on which internal control is based and is considered the main seed in the control system besides giving confirmation to all operations And the events that take place within the company first-hand and are fully informed of the daily and future conditions of the company, and on this basis international companies have taken care of the internal audit function and issued its own standards in achieving the goals and pillars of institutional control and thus its impact on the continuation Company banner. 
STATEMENT OF THE PROBLEM The internal audit profession faces enormous changes since the end of the twentieth century until now, which requires companies to fully adapt to these changes that they are experiencing, and the problems faced by these companies and the economic conditions that beset the world of finance and business require learning about their basic aspects and how to work to address them in their stages The early years before it worsened and led to bankruptcy, and from this standpoint, institutional control has succeeded in improving the relationship between companies and many who are interested in their affairs and finding ways to find out the main causes of failure of some of them and their lack of continuity and volatility and decline in profits through His principles focused mainly on the profession of internal auditing.

As a result of the foregoing, the problem of the study is embodied in that the weakness and lack of the concept of institutional control and the failure to clearly diagnose its principles and objectives will ultimately lead to a weakening of the role of internal auditing with (Iraqi private banks), which will reflect on its survival and continuity and expose the interests of its shareholders to high risks.

Objectives of the Study: The current study seeks to achieve each of the following goals: -

1. Explain the extent to which the principles and foundations of institutional control can be applied in Iraqi private banks, and then explain the impact of the modern internal audit function to support institutional control.

2. To arrive at a proposed model for the work of the Iraqi private banks, stating the impact of the modern internal audit function to support institutional control, and another model for the functions of the modern internal audit function under institutional control.

RESEARCH METHODOLOGY: This chapter explains the methodology adopted by the researcher to conduct the proposed study. Both primary and secondary data were used for this research. The primary data was collected using a well-organized questionnaire, which was managed personally as the questionnaire was distributed to a number of Iraqi private banks. Secondary data was collected from published research results, articles, books, previous studies, organizations' bulletins, annual reports of manufacturing units and from various websites.

The sample technique used for the study is a simple random sampling method. Both traditional and advanced statistical tools have been applied to data analysis. The data collected was collected in an Excel sheet and statistical packages were used for SPSS 19 
and version. Statistical tools for the empirical factor analysis model and structural equation were used to analyse data and reach meaningful conclusions.

Factor analysis is defined as a mathematical model that shows the relationship between a large group of variables in terms of a few basic factors, The adoption of correlation coefficients to explain the relationship between variables is very difficult, especially when there are a large number of variables, so a global analysis is a way to reduce these relationships to facilitate their interpretation, The goal of using factor analysis is that the variables are evaluated based on the relationships between these variables and not on the separate treatment of each variable from the rest of the variables and tested when using the analytical examination, as well as this analysis shows us the importance of each of these variables and know if there is a variable It appears independent of the rest of the variables, or knowing that it has a relationship with other influencing variables and determining the amount or quantity of the influence of each.

Among the methods of global analysis used in determining the factors affecting is the factor model that interprets the global model of $\mathrm{K}$ from the variables seen for a sample of its size $\mathrm{n}$ on the basis of a linear function of $\mathrm{m}$ from the common factors and $\mathrm{K}$ of the only factors for each variable

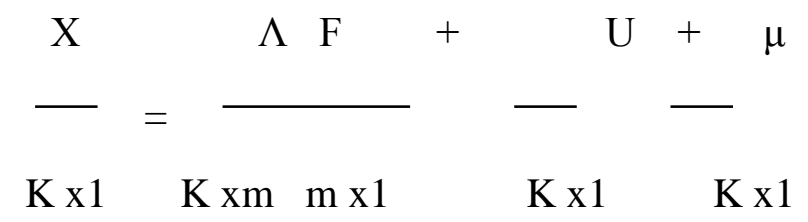

The directors of the averages for each of the common and single factors are two zeros, according to the assumption of $\mu$ the wave of the variable circles is zero, that is, the global pattern will be as follows

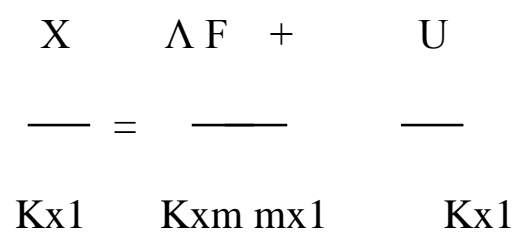

Factorial analysis can be briefly described as describing and interpreting phenomena or attributes of variables on the basis of reaching the highest level of information with the lowest possible number of factors that express the relationships between the variables (Harman, 1976, P25) 
The study hypothesis: The research is based on the basic hypothesis that:

The existence of an internal audit is effective and successful takes into account the concept of institutional control and its objectives and principles and its effects will be reflected in the end on the continuity of joint stock companies (Iraqi private banks) in its high efficiency and effectiveness of the performance.

\section{Maintaining a basic preference for corporate governance}

Institutional control is a product of the roles that some of the agencies entrusted with the management, supervision and control processes that are accountable for achieving the goals and objectives of the company or for the level of financial reporting. Therefore, institutional strengthening is required with the availability of key elements of its success and the delivery of correct, clear and complete information to all parties of interest. , With dealing in integrity, objectivity and honesty in implementing the company's operations and in its management, and holding those responsible in the company accountable for the consequences of their actions and the use of available funds as well as what companies need to amend in the regulations and legislations that lead to strengthening institutional control Feast, and there are some basic props that lead to the consolidation and strengthening of the institutional strengthening of control as follows in Figure:

Figure (1) basic preference for corporate governance

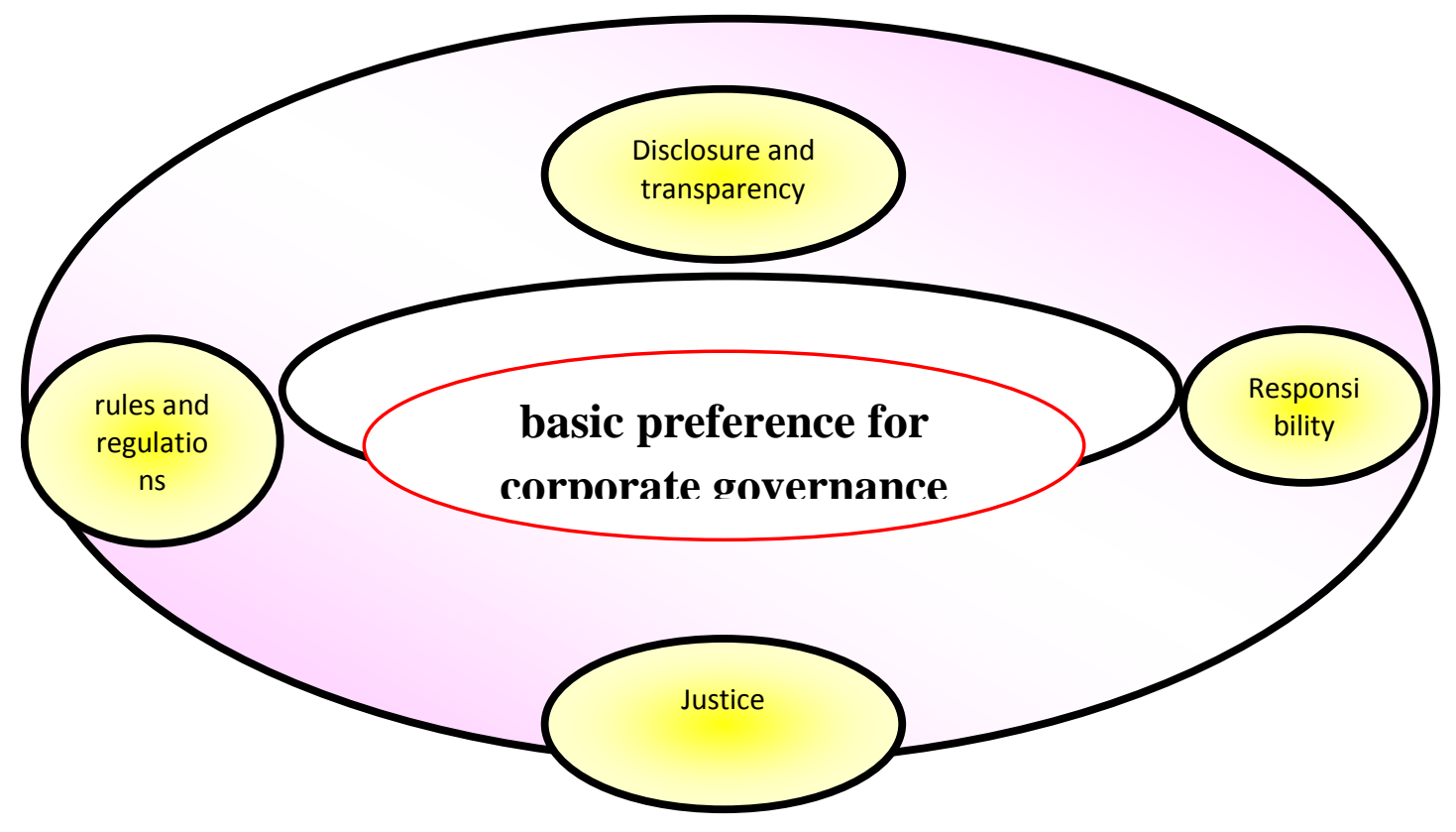


1-Disclosure and transparency: It is an important pillar to ensure justice, integrity and trust in the procedures of managing companies and managing their members and making rational decisions, as this pillar provides the delivery of correct, clear and complete information to all parties involved in the company's activity and allows the field to prepare useful analyses of the company's operations and the basics Its economic, financial information and non-financial information, The importance of transparency in accounting information has emerged after the increasing economic role of financial markets and after published financial reports have become an important source of information for decisionmaking, Transparency is represented by providing information for the purpose of protecting the future of shareholders and to make society recognize that the company is able to fulfils its obligations, and therefore transparency is based on accountability for executive management by shareholders. (Japan Committee, 2001, P8).

2- Responsibility: The primary responsibility for good institutional control rests with the managers, and the legal role of auditors is to provide the shareholders with an objective and independent guarantee based on financial reports and other information provided by the company. This vital role justifies the private site of auditors under the Companies Law. (Hermanson \& Rittenberg, Op.Cit, P30)

Responsibility is linked to the pillar of accountability in terms of corrective actions or punishment for mismanagement, and it is naturally included in the line of delegation of powers in each company, where responsibility helps in implementing the company's operations better by identifying the workers to the work required of them and holding them accountable for them.

And that every manager - regardless of his level - is responsible for his responsibility center, and the responsibility centre is a part or sub-unit of the organization, so that his manager can be held accountable for a set of activities specified in him .. The higher the managerial level of the manager, the greater the responsibility centre he manages and the more The number of reports submitted to him from his subordinates. (Jane, 2003, p. 316)

3- Achieving justice: respecting and recognizing the rights of all parties with interests that guarantee equality, and among these parties are the interests of the minority shareholders , Whereas, the Organization for Economic Cooperation and Development (OECD) is concerned with protecting the rights of the interests of the minority shareholders, by establishing systems that prevent workers inside the company, including the managers and members of the board of directors, from benefiting from their position in the company by 
trading in shares, and members of the board of directors must announce and disclose any interests Material in the company's operations.( Lindow, 2002, P12).

4- Laws and Legislations: The presence of laws and legislations clarifying the rights and duties of shareholders such as the right to vote, the right to elect the members of the Board of Directors and the right to appoint and dismiss the auditor, as well as the community's rights over the company and their duties towards it, are considered as the main safety valve that guarantees institutional control, where Institutional control rules overlap with a number of laws, such as: corporate laws, capital markets, banks, deposit and central custody, accounting and auditing, competition and antitrust, taxes, labour, privatization and the environment. (Elisabeth, 2002, P337).

To the fact that the various forms of contracts between all the parties involved in the company represent the cornerstone of organizing contractual relations between them, which can work to ensure the rights of each of them, and the importance of institutional control comes legally to overcome the negatives of implementing contracts that can result from negative practices that violate formulas The contracts concluded or laws, decisions and basic regulations governing the company, Hence, many legal persons affirm the responsibilities of trust custody, which the managers perform before the other parties of the company to guarantee their rights. (Roth -, 2003, p. 48)

After presenting the foundations of institutional control, the researcher sees that it has become an urgent necessity to be applied and a matter of seriousness in an era of globalization, privatization and free economy, and the increasing role of joint-stock companies and financial markets in the international economy at the expense of the government sector, which led to an increasing phenomenon of conflict of competencies, powers and interests, but rather contradictory phenomenon Interests Given the multiplicity of the parties associated with the company and the breadth of its interests, the possibilities of conflict of interests are no longer confined only to the interests of the company's management and the interests of its shareholders according to the concepts of the agency theory, but conflicts of interests of the company with its independent moral personality and the interests of all children Ruff related to this through seeking to maximize its profits and keenness to continue, where it can be said that these pillars are linked to each other by a mutual relationship that works together to achieve effective control and that the absence of any of them leads to weakening control and as a result weakening institutional control.

\section{The relationship of institutional control with the modern internal audit function}

By reviewing the concept of the internal audit function and its relationship to institutional control that has emerged as a critical part of its infrastructure, and for the internal audit 
function to be effective and effective, it can significantly enhance the success and continuity of the company as follows: -

1- Serving the internal audit function of the parties involved and contributing to the integrated control in an integrated manner such as the board of directors, the executive director, the audit committee, the external auditor, moreover, the internal audit function adds value to the government units with the decision such as organizational units (tax department), technical management Information and operations through the reports and information that you provide about giving objective confirmation about the ongoing operations and events in the company.

2- Unifying many of the activities carried out by the internal audit function with the company's supervisory construction. This is what is instructed to perform important oversight activities united with the company's supervisory operations. This raises questions about what is the appropriate role that this function plays and that serves a direct part of the regulatory system in exchange for Emphasis on the effectiveness and efficiency of control in the company.

3- It is recognized that the internal audit function sources are internal within the company, sometimes external sources are used to perform the role of the internal audit function, although this procedure creates additional independence and improves the effectiveness of institutional control, but at the same time takes into account that the main part of the control building The institutional (internal audit function) is not part of the corporate entity, although the broad and developed organizational vision is to make the sources of the internal audit function internally and within the company because this will strengthen institutional control.

4- The clear expansion of the role of the internal audit function in the field of advisory services and confirmation services for the effectiveness of institutional control operations confirms the possibility of the job being exposed to risks.

On this basis, a framework can be established to build a modern internal audit function that is compatible with recent developments and with the goals of institutional control.

\section{Internal audit function}

The internal audit procedures were in the past, after the implementation of the accounting operations, where the detection of fraud and errors and the control of accounting data represented the primary work of the internal audit, that is, verification to ensure the integrity of the accounting records and data and the preservation of the company's assets. 
At the end of the nineteenth century, a logical development occurred for the internal audit function, as it was considered a calendar activity that assists the administration in its ruling on how to carry out the various activities within the company, where the internal auditor was seen as an assistant to the external auditor, aimed at reducing the cost of the external auditor.

On the basis of the foregoing, the objectives of the internal audit became limited to the following two objectives:( Tone, 2004, p. 304)

The first goal: - Protection.

The second goal: - Evaluation.

Protection: This goal defines the nature of the internal audit function, whereby the concept of protection means checking past events and facts to verify the validity of the accounting control application and that the company's assets have been accounted for and that the separation function has been separated from the implementation function and the accounting function and finally the internal control is evaluated in terms of division of business, including Achieves the sequence of the implementation of operations, and based on the above, it is sometimes called "financial auditing".( William R. Kinney.2009.p34)

The second objective - evaluation: This goal represents the recent development of the internal audit, as it is an extension of the first goal as it is to ensure that every part of the company's activity was monitored. Accordingly, achieving this goal is through establishing an internal audit program through the organizational map and not through financial reports. In this case, the internal auditor is a representative of public administration and not financial management, therefore because he assesses the convergence of the objectives of the subsystems with the goals set by the senior management It has or the extent to which the system is in line with the requirements of the administration (Church,2001, p. 65-80)

\section{The impact of the evolution of the concept of internal audit in support of institutional control}

Within the framework of the institutional control and its definition issued by the Institute of Internal Auditors (IIA), "It is a series of procedures used by representatives of stakeholders to provide supervision, management and control of risks and emphasize the adequacy of controls to avoid these risks, which leads to direct contribution to achieving the goals and values of the company to achieve effectiveness The agency, bearing in mind that the performance of institutional control activities is the responsibility of the company's stakeholders, "It is possible to shift specifically to the role of the internal audit function. Within this context, (IIA) internal audit was defined as an independent activity 
and substantive confirmation of an advisory nature. It aims to add value to the company and improve its operations, and internal audit helps the company achieve its goals by adopting an objective approach to evaluate and improve the effectiveness of risk management and the effectiveness of oversight and the effectiveness of the corporate control management process. (AICPA 2003, P5)

The researcher believes that by comparing the two definitions, the emergence of a few similar general elements, especially the elements of assurance, risk and control, and therefore the internal audit function is a player in the front line and important in implementing the two main institutional control activities, namely risk control and providing confirmation in relation to oversight, as the internal auditor's efforts provide risks Critical input to institutional control shareholders such as management and the audit committee, while others describe the audit function "as the eyes and ears of the audit committee".

To show the impact of the development of the concept of internal audit on supporting organizational control, (Chapman \& Anderson) believes that the modern definition of internal audit provides a modern picture of the profession in six main directions: (Basell, 1999, P7)

1. The first trend: internal audit is only an objective activity that is not necessarily established within the company, i.e. external parties can provide internal audit services, which guarantees the quality of internal audit services, which can be obtained through the use of external sources.

2. The second trend: the scope of internal auditing includes consultancy activities, so the modern definition of internal auditing presents the profession as directed to customer service, as it focuses on the main issues, oversight, risk management and institutional control.

3. The third direction: the internal audit aims to add value to the company and improve its operations, so it emphasizes the essential contribution of the internal audit to the company.

4. The fourth trend: internal audit takes into account the company as a whole, so modern auditing looks at internal audit more broadly in helping the company achieve its overall goals.

Conclusion

5. Fifth trend: The modern definition assumes that the control tools do not exist except to help the company manage risks and to promote effective institutional control, and this 
perspective works to broaden the scope of internal audit prospects in a significant way as it broadens the scope of the internal audit work to include risk management and control and operations control.

6. The Sixth Direction: The modern definition sees that the professional commitment of internal auditing may be its most valuable asset, and that strict standards for the profession guarantee the quality of the profession.

\section{Data Analysis in the Iraqi private banks}

This paragraph deals with the statistical results of each of the paragraphs of the axes included in the questionnaire in order to ascertain the validity of the hypothesis upon which it was based in the study.

First: Disclosure and transparency

The appropriate variables that were included in the global analysis of the first axis questions were identified a paragraph (disclosure and transparency) which are as follows:

Table number (1)

Variants of paragraph (disclosure and transparency)

\begin{tabular}{|c|c|c|}
\hline $\mathbf{N}$ & الاسئلة & $\mathbf{V}$ \\
\hline \multirow[t]{3}{*}{1} & The bank has a transparent structure in disclosing & $\mathbf{x 1}$ \\
\hline & The size of the total shares held in the bank & $\mathbf{X 2}$ \\
\hline & The share of the major shareholders or the majority shareholders in the bank & X3 \\
\hline \multirow[t]{5}{*}{2} & The bank has disclosed sensitive information to the public related to- & \\
\hline & he financial and operational performance of the bank & $\mathrm{X} 4$ \\
\hline & $\begin{array}{l}\text { The commercial operations carried out by the bank and its competitive position } \\
\text { from other banks }\end{array}$ & X5 \\
\hline & The background of the bank's board members & $\mathrm{X6}$ \\
\hline & Changes in ownership rights within the bank & $\mathrm{X7}$ \\
\hline 3 & Disclosure of recent information on the Internet related to: & \\
\hline
\end{tabular}


QALAAI ZANIST SCIENTIFIC JOURNAL

A Scientific Quarterly Refereed Journal Issued by Lebanese French University - Erbil, Kurdistan, Iraq

Vol. (4), Issue (4), Fall 2019

\begin{tabular}{|c|c|c|}
\hline & Operations and events that have a material impact on the bank & $\mathbf{X 8}$ \\
\hline & The ownership structure of shares within the bank & X9 \\
\hline & The bank's financial reports & $\mathbf{X 1 0}$ \\
\hline & the organizational structure of the bank & $\mathrm{X11}$ \\
\hline 4 & $\begin{array}{l}\text { The Board of Directors determines the types of reports that need to be disclosed in } \\
\text { a transparent manner and that work in the bank requires, and a regular pattern is } \\
\text { followed during the year. }\end{array}$ & $\mathrm{X} 12$ \\
\hline 5 & The bank disclosed its program for obtaining its shares & $\mathbf{X 1 3}$ \\
\hline 6 & $\begin{array}{l}\text { The bank shall disclose the working methods used in determining the remuneration } \\
\text { of the board member in its annual lists for all shareholders. }\end{array}$ & X14 \\
\hline 7 & $\begin{array}{l}\text { The Board of Directors has a clear and written policy on transparency and disclosure } \\
\text { of the bank's policy, strategy and goals that is available to inform the general body } \\
\text { responsible for its business. }\end{array}$ & $\mathbf{X 1 5}$ \\
\hline 8 & $\begin{array}{l}\text { The bank's annual report includes a prediction of the bank's profitability in the } \\
\text { coming fiscal year. }\end{array}$ & X16 \\
\hline 9 & $\begin{array}{l}\text { Any conflict of interest that occurs within the bank should be disclosed through its } \\
\text { policies, and there is a clear mechanism for disclosing this and eliminating it. }\end{array}$ & X17 \\
\hline 10 & $\begin{array}{l}\text { The bank's annual report specifically addresses the practice of managing risks arising } \\
\text { from institutional control }\end{array}$ & X18 \\
\hline
\end{tabular}




\begin{tabular}{|l|l|c|}
\hline 11 & $\begin{array}{l}\text { The director shall observe confidentiality and avoid disclosing any information } \\
\text { related to the bank obtained as a member of the board of directors without } \\
\text { obtaining a license from the board of directors in order to reinforce the principles of } \\
\text { institutional control. }\end{array}$ & $\times 19$ \\
\hline 12 & $\begin{array}{l}\text { The manager informs the council in advance of any possible process that includes } \\
\text { his participation or the participation of his immediate relatives or business partners } \\
\text { regarding the bank's shares in furtherance of the principles of institutional control }\end{array}$ & $\times 20$ \\
\hline
\end{tabular}

The significance of factors loads test: The factors loads significance test for the matrix of the rounded factors shown in Table (1) was calculated by calculating the standard error of the loads for each factor according to the following formula

$$
\mathrm{S}(\mathrm{ajp})=\operatorname{Sr}(\mathrm{xi}, \mathrm{yi}) \sqrt{\frac{\mathrm{k}}{\mathrm{K}+1-\mathrm{P}}}
$$

The standard normative for first factor is

$$
\text { Sajl }=0.158 \sqrt{\frac{20}{20+1-1}}=0.158
$$

Matrix factors retained for answers disclosure and transparency

\begin{tabular}{|c|c|c|c|c|c|}
\hline & \multicolumn{5}{|c|}{ Factors } \\
\hline $\begin{array}{c}\text { Disclosure and } \\
\text { transparency }\end{array}$ & 1 & 2 & 3 & 4 \\
\hline $\mathrm{X} 1$ & .892 & $7.928 \mathrm{E}-02$ & .201 & $-8.191 \mathrm{E}-02$ & $4.700 \mathrm{E}-02$ \\
\hline $\mathrm{X} 2$ & .744 & .456 & .256 & -.232 & $6.087 \mathrm{E}-02$ \\
\hline $\mathrm{X} 3$ & .608 & .402 & .445 & -.189 & .114 \\
\hline $\mathrm{X} 4$ & .865 & -.113 & .280 & .108 & .109 \\
\hline $\mathrm{X} 5$ & .833 & .118 & .244 & $3.150 \mathrm{E}-02$ & -.182 \\
\hline
\end{tabular}


QALAAI ZANIST SCIENTIFIC JOURNAL

A Scientific Quarterly Refereed Journal Issued by Lebanese French University - Erbil, Kurdistan, Iraq

Vol. (4), Issue (4), Fall 2019

ISSN 2518-6566 (Online) - ISSN 2518-6558 (Print)

\begin{tabular}{|c|c|c|c|c|c|}
\hline $\mathrm{X} 6$ & .808 & $1.046 \mathrm{E}-02$ & -.206 & .377 & $7.895 \mathrm{E}-02$ \\
\hline $\mathrm{X} 7$ & .862 & -.112 & .147 & .101 & -.140 \\
\hline $\mathrm{X} 8$ & .290 & .857 & .121 & $9.577 \mathrm{E}-02$ & .119 \\
\hline $\mathrm{X9}$ & .245 & .859 & $5.241 \mathrm{E}-02$ & .154 & $-2.892 \mathrm{E}-02$ \\
\hline $\mathrm{X} 10$ & $-6.396 \mathrm{E}-03$ & .746 & $4.578 \mathrm{E}-02$ & .128 & .120 \\
\hline $\mathrm{X} 11$ & -.196 & .948 & .165 & .160 & $9.940 \mathrm{E}-02$ \\
\hline $\mathrm{X} 12$ & .316 & .293 & .722 & $4.453 \mathrm{E}-02$ & .137 \\
\hline $\mathrm{X} 13$ & .104 & .338 & .264 & .711 & $-7.296 \mathrm{E}-02$ \\
\hline $\mathrm{X} 14$ & $-4.893 \mathrm{E}-02$ & .292 & $-6.296 \mathrm{E}-02$ & .462 & .239 \\
\hline $\mathrm{X} 15$ & .305 & $2.547 \mathrm{E}-02$ & .691 & .451 & $-3.288 \mathrm{E}-02$ \\
\hline $\mathrm{X} 16$ & .729 & .454 & -.232 & .142 & .398 \\
\hline $\mathrm{X} 17$ & .348 & $-2.009 \mathrm{E}-03$ & .174 & .331 & .216 \\
\hline $\mathrm{X} 18$ & .389 & .217 & $7.520 \mathrm{E}-02$ & $5.411 \mathrm{E}-02$ & $7.507 \mathrm{E}-02$ \\
\hline $\mathrm{X} 19$ & .211 & $8.762 \mathrm{E}-02$ & $-2.663 \mathrm{E}-02$ & $-5.552 \mathrm{E}-03$ & .659 \\
\hline $\mathrm{X} 20$ & -.358 & .151 & .242 & .212 & .682 \\
\hline & & & & & \\
\hline
\end{tabular}

This factor is of great and distinct importance in influencing disclosure and transparency, as it indicates 37,634 of the total variance, so it is considered the primary factor for the interpretation of the correlation matrix and may include the following variables represented in the above table: - $(\mathrm{x} 3, \mathrm{x} 16, \mathrm{x} 2, \mathrm{x} 6, \mathrm{x} 5, \mathrm{x} 7, \mathrm{x} 4, \mathrm{x} 1)$

The most important factors that emphasize proper disclosure for all banks is that they have a transparent structure in disclosure, and this is represented in the first question, paragraph (a): the size of the total shares held in the bank and then come in terms of importance, the paragraphs of the second question, concerning the disclosure of sensitive information to the public Where paragraph (a) came to disclosure of the financial and operational performance of the bank, and then paragraph (h) changes in ownership rights within the bank, and paragraph (b) commercial operations carried out by the bank and its competitive position from other banks and then paragraph (c) backgrounds Board members, and then come In the importance of paragraph (b) within the first question, which is the disclosure 
of the share of the major shareholders or the majority shareholders of the shares, and then comes in terms of importance according to the matrix of the rotating factors Question No. (8) represented by: The bank's annual report includes a prediction of its profitability in the next fiscal year And the last paragraph in the analysis of the first factor was within the first question, paragraph (c) disclosure of ownership of members of the Board of Directors of shares.

This means that all paragraphs of the first question and the second question fall within the first factor in addition to the eighth question.

As for the results of the second degree factors, as it comes in the second degree of importance in explaining the relationship between the variables, as it explains $18.376 \%$ of the total variance, it is represented by the variables (X10, X8, X9, X11) respectively, where all these paragraphs fall within the third question, which is the disclosure of recent information On the Internet related to the (w) the organizational structure of the bank, (b) the ownership ownership structure within the bank, (a) operations and events that have a material impact on the bank, (c) the financial reports of the bank.

The results of the third degree factors, where this factor comes third in terms of its importance in explaining the relationship between the variables, as the relative importance of this factor constitutes $8.428 \%$ of the total variance and includes the variables (X15 and X12), respectively. Question No. (4) came first from the analysis Which is, the Board of Directors determines the types of reports that must be disclosed transparently and that work in the bank requires, and a regular pattern follows during the year. As for the second paragraph, question No. (7) represented by the Board of Directors has a clear and written policy regarding transparency and disclosure about a policy The strategy and goals of the bank will be Available to inform the general body responsible for its work.

While the results of the analysis of the factors of the fourth degree included that the relative importance of this factor constituted $7.587 \%$ of the total variance and included the variable (X13) represented by question No. (5) which is, the bank discloses its program of employee access to its shares.

As for the results of the analysis of the factors of the last and fifth degrees in terms of importance in explaining the relationship between the variables, where it explains $6.427 \%$ of the total variance, represented by the variables (X20, X19), represented by question No. (12), the director informs the council in advance of any possible process that includes his or his relatives 'participation The direct or his business partners regarding the bank's shares in furtherance of the principles of institutional control, and question No. (11) the director takes into account confidentiality and avoids disclosing any information related to 
the bank obtained as a member of the board of directors without obtaining a license from the board of directors in order to reinforce the principles of institutional control.

\section{Second: Responsibility}

As for the second paragraph of the first axis (responsibility), the following variables have been named according to the following schedule: -

\section{Table No. (3)}

Variables by paragraph II (responsibility) first axis

\begin{tabular}{|c|c|c|}
\hline $\mathbf{N}$ & الاسئلة & $\mathbf{V}$ \\
\hline 1 & $\begin{array}{l}\text { All information and topics to be discussed in advance should be submitted to the } \\
\text { Board in a sufficient time for study and analysis, so that the members of the Board } \\
\text { of Directors can exercise their duties in the direction and guidance of the bank's } \\
\text { strategy and supervise the senior management. }\end{array}$ & $\times 21$ \\
\hline \multirow[t]{5}{*}{2} & The Board of Directors is responsible for: & \\
\hline & $\begin{array}{l}\text { A specifying the duties and powers of each official within the bank for the purpose } \\
\text { of accountability }\end{array}$ & $\mathbf{X 2 2}$ \\
\hline & $\begin{array}{l}\text { By setting ethical rules that can be used to eliminate any bias in interests in favor of } \\
\text { one group and not the other }\end{array}$ & $\times 23$ \\
\hline & $\begin{array}{l}\text { To supervise the process of managing and identifying risks in a way that ensures } \\
\text { that the working employees carry out their duties within the scope of the powers } \\
\text { vested in them }\end{array}$ & $\times 24$ \\
\hline & $\begin{array}{l}\text { Reporting the corrective actions that are taken immediately after an infringement } \\
\text { has occurred in those authorities and powers of the bank }\end{array}$ & $\times 25$ \\
\hline 3 & The bank manager is responsible for: & \\
\hline
\end{tabular}


QALAAI ZANIST SCIENTIFIC JOURNAL

A Scientific Quarterly Refereed Journal Issued by Lebanese French University - Erbil, Kurdistan, Iraq

Vol. (4), Issue (4), Fall 2019

\begin{tabular}{|l|l|c|}
\hline & $\begin{array}{l}\text { determination of sufficient time in the study of the topics presented to the Board } \\
\text { and related to the bank's business and based on its primary responsibility }\end{array}$ & $\mathbf{X 2 6}$ \\
\hline $\begin{array}{l}\text { With regular attendance at Council meetings to familiarize themselves with the } \\
\text { topics and discussions raised in the meeting, in the interest of his responsibility. }\end{array}$ & $\mathbf{X 2 7}$ \\
\hline $\begin{array}{l}\text { about the bank } \\
\text { the requirements of responsibility }\end{array}$ & $\mathbf{X} 28$ \\
\hline $\begin{array}{l}\text { Participation in defining the bank's short, medium and long-term strategies to meet } \\
\text { time, or whose service is renewed by the Board of Directors }\end{array}$ & $\mathbf{X} 29$ \\
\hline
\end{tabular}

The answers mentioned in the questionnaire, which pertain to the second paragraph of the first axis (responsibility), were analysed according to the global analysis. After analysing the correlations of the variables, through the baseline values shown in Table No. (4), there are two main factors that affect the degree of their use by the bank on responsibility. It is represented by basic values that are greater than one and ranked according to the importance of each factor's influence on institutional control.

Table No. (4)

Basal values and contrast ratio factor of the total variation

\begin{tabular}{|c|c|c|c|}
\hline Factor & $\begin{array}{c}\text { baseline } \\
\text { values }\end{array}$ & $\begin{array}{c}\text { contrast } \\
\text { ratio }\end{array}$ & $\begin{array}{c}\text { Society } \\
\text { variation }\end{array}$ \\
\hline 1 & 4.524 & 45.240 & 45.240 \\
\hline 2 & 2.295 & 22.954 & 68.194 \\
\hline 3 & .869 & 8.690 & 76.884 \\
\hline 4 & .771 & 7.713 & 84.596 \\
\hline
\end{tabular}




\begin{tabular}{|c|c|c|c|}
\hline 5 & .581 & 5.812 & 90.408 \\
\hline 6 & .469 & 4.688 & 95.096 \\
\hline 7 & .274 & 2.736 & 97.833 \\
\hline 8 & .108 & 1.081 & 98.914 \\
\hline 9 & $7.120 \mathrm{E}-02$ & .712 & 99.626 \\
\hline 10 & $3.741 \mathrm{E}-02$ & .374 & 100.000 \\
\hline
\end{tabular}

This factor constitutes a great and distinct importance in influencing responsibility, as it indicates $45.240 \%$ of the total variance, so the main factor for the interpretation of the correlation matrix is the following variables may include the variables X21, X27, X26, $\mathrm{X} 29, \mathrm{X} 28)$ ) respectively in terms of significance and note that the four variables The first (X27, X26, X29, X28) falls within the third question of (responsibility) which is that the bank manager is responsible for: where it came first in terms of importance Paragraph (a) is positive participation when attending board meetings and in neutral discussions about the bank, And then it is followed by paragraph (w) in terms of importance, which is participation in defining strategic strategies, medium and long-term for the bank to meet the requirements of responsibility, after which paragraph (a) comes to spend enough time in studying the issues presented to the board and related to the bank's business and based on its primary responsibility, and finally paragraph (b) attend the board meetings regularly to get acquainted with the topics and discussions raised in the meeting in order to His responsibility. In terms of importance and the first question and its content, all information and topics to be discussed in advance and sufficient time for study and analysis shall be submitted to the Council, so that

The members of the Board of Directors are able to exercise their duties in the guidance and direction of the bank's strategy and in supervising the senior management.

As for the second factor, where it comes in the second degree of importance in explaining the relationship between the variables, as it explains $22.954 \%$ of the total variance, it is represented by the variables (X23, X22, X25) respectively, and that all the above paragraphs fall within the second question of (responsibility) represented by the board of directors Responsible for: where it came first in terms of the importance of paragraph (w) in the first rank, which is reporting on corrective actions that are taken immediately after 
an overrun occurred in those authorities and powers in the bank, and then comes second in terms of importance, paragraph (a) which includes the duties and powers of each Bank official For the purpose of accountability, the third place in terms of importance is represented in paragraph (b) of ethical rules that can be used to eliminate any bias in interests in favor of one group and not the other.

And by observing the previous analysis, the extent of the banks 'interest in the responsibility clause is noted, and this is what applies to the foundations of institutional control except for the paragraph on supervision of the risk management process, and this is what was mentioned previously by the lack of interest of most banks in the process of identifying and managing risks, despite the importance of this process in relation to the work of these banks and being able to determine the ability The bank is to continue, and if the bank does not take a risk ratio in its business, it will not be able to achieve any returns as losses arise as a result of the inability to manage risks or the failure to obtain the appropriate returns for these risks, so the bank must have a management system for the brain A good method allows for matching between returns and risks within the limit permitted by the bank's position and strategy, but its effectiveness depends on the existence of a good institutional control system, otherwise efforts to manage these risks will be ineffective, and good control works to reduce losses that may arise as a result of the lack of systems Internal control and control, or because of the expansion in taking risks, as providing good control systems includes independent monitoring of the bank's compliance with written policies and the established risk limits in order to protect the rights of depositors.

For the purpose of showing the extent of each bank's agreement with the results of the global analysis of the first factor of the paragraph (responsibility), the researcher used the percentage method.

\section{third: Justice}

As for the fourth paragraph of the first axis (Justice), the following variables were named according to the following schedule:

Table No. (5)

Variables by paragraph II (Justice) first axis

\begin{tabular}{|c|c|c|}
\hline $\mathbf{N}$ & \multicolumn{1}{|l|}{} & $\mathbf{V}$ \\
\hline & & \\
\hline
\end{tabular}




\begin{tabular}{|c|c|c|}
\hline 1 & $\begin{array}{l}\text { including the interests of minority shareholders in the bank for the purposes of } \\
\text { justice. }\end{array}$ & X31 \\
\hline 2 & $\begin{array}{l}\text { The bank has a working guide for institutional control that guarantees justice to all } \\
\text { parties involved with the institution. }\end{array}$ & X32 \\
\hline 3 & $\begin{array}{l}\text { The guide identifies the main stakeholders whose interests must be taken into } \\
\text { consideration in order to achieve justice for them in the bank to achieve justice. }\end{array}$ & X33 \\
\hline 4 & $\begin{array}{l}\text { The shareholders of the ruling proportions give the necessary attention to the } \\
\text { interests of the majority shareholders and provide assistance to elect the majority } \\
\text { of the independent board members from abroad so that they can protect the } \\
\text { interests of all shareholders }\end{array}$ & X34 \\
\hline 5 & $\begin{array}{l}\text { The structure of the remuneration of the members of the Board of Directors is fair } \\
\text { and sufficient with the duties and responsibilities incumbent on them in the } \\
\text { Council. }\end{array}$ & X34 \\
\hline 6 & $\begin{array}{l}\text { The director shall perform the necessary due diligence in carrying out his duties as a } \\
\text { member of the Board of Directors in the interest of justice. }\end{array}$ & X36 \\
\hline 7 & $\begin{array}{l}\text { The Chairman of the Board of Directors is obligating all members of the Board to } \\
\text { attend the meetings and giving them the opportunity to express their views freely } \\
\text { and in a responsible manner in order to achieve justice. }\end{array}$ & X37 \\
\hline 8 & $\begin{array}{l}\text { The Chairman of the Board guarantees that all members fulfill their full roles in the } \\
\text { Board's discussions in order to achieve justice. }\end{array}$ & X38 \\
\hline
\end{tabular}

It has been analysing the answers contained in the questionnaire, which is for the fourth paragraph of the first axis (justice) by factor analysis shows after analysis of the links 
variables through the basal values shown in Table No. (6) There are two factors that affect the degree used by the bank to justice represented basal values that are greater than one and ranked according to the importance of the impact of each factor on the institutional control.

Table No. (6)

Basal values and contrast ratio factor of the total variation

\begin{tabular}{|c|c|c|c|}
\hline Factor & $\begin{array}{c}\text { baseline } \\
\text { values }\end{array}$ & $\begin{array}{c}\text { contrast } \\
\text { ratio }\end{array}$ & $\begin{array}{c}\text { Society } \\
\text { variation }\end{array}$ \\
\hline 1 & 4.043 & 50.538 & 50.538 \\
\hline 2 & 1.425 & 17.811 & 68.349 \\
\hline 3 & .906 & 11.319 & 79.668 \\
\hline 4 & .631 & 7.890 & 87.558 \\
\hline 5 & .444 & 5.553 & 93.111 \\
\hline 6 & .315 & 3.933 & 97.044 \\
\hline 7 & .152 & 1.896 & 98.939 \\
\hline 8 & $8.484 \mathrm{E}-02$ & 1.061 & 100.000 \\
\hline & & & \\
\hline
\end{tabular}

This factor constitutes a great and distinct importance in influencing justice, as $50.538 \%$ of the total variance indicates, so the main factor for the interpretation of the correlation matrix is considered. The following variables have included the variables ( $\mathrm{x} 44, \mathrm{x} 43, \mathrm{x} 45$, $\mathrm{x} 42, \mathrm{x} 41)$ respectively, where the paragraph (x41) comes first In terms of importance, they are represented in question No. (1), and the bank has a working guide for institutional control that guarantees fairness to all interested parties with the bank. Question No. (2) is ranked second according to what is stated in the above table as in the variable (x42), and it specifies the guide of the main stakeholders whose interests must be taken into consideration to achieve justice for them in the bank to achieve justice, and then question No. (5) which states that leads The director has the necessary careful care in conducting his business as a member of the board of directors in order to achieve justice, and question No. (3) comes in terms of importance, giving shareholders with ruling proportions the necessary degree of attention to the interests of majority shareholders and providing assistance to elect the majority of independent board members from abroad so that they can 
protect the interests of All shareholders including So the interests of minority shareholders in the bank for the purposes of justice, and finally comes the question no. (4) came

In the last rank and its content, the structure of the remuneration of the members of the Board of Directors is fair and sufficient, along with the duties and responsibilities incumbent on them in the Council.

As for the second factor, where it comes in the second degree of importance in explaining the relationship between the variables, as it explains $17.811 \%$ of the total variance. In the discussions of the Council in the pursuit of justice, and then Question No. (8) comes in the last rank, and the Board of Directors is actually working collectively to confront any member of the Board of Directors who claims to himself the authority to make decisions without benefiting from the opinions of other members to achieve justice.

Through the results of the analysis, it was revealed the extent of the banks 'agreement with the pillars of institutional control to achieve justice, as it was found that the majority of banks strive to achieve justice for all parties without favouring one at the expense of another, by providing a balanced system within which decisions are taken in a manner that takes into account all relevant parties, especially young The shareholders, either in terms of having a working guide for institutional control that guarantees justice for all individuals with an interest with the bank Note that most of the banks answered this paragraph by agreement to indicate the extent of the desire of these banks towards achieving justice, although the banks do not have a working guide for institutional control, but according to what you understand During the ongoing meetings with employees of banks that the main objective that you want is a result of their work lies in achieving fair treatment for all parties.

For the purpose of showing the extent of each bank's agreement with the results of the global analysis of the first factor of the paragraph (justice) in terms of importance, the researcher used the percentage method.

\section{forth: rules and regulations}

As for the fourth paragraph of the first axis (rules and regulations), the following variables were named according to the following schedule:

Table No. (7)

Variables by paragraph II (rules and regulations) first axis

\begin{tabular}{|c|c|c|}
\hline $\mathbf{N}$ & $\mathbf{V}$ \\
\hline
\end{tabular}




\begin{tabular}{|c|c|c|}
\hline 1 & $\begin{array}{l}\text { The Board of Directors has a clear policy to monitor the bank's full compliance with } \\
\text { laws, regulations and instructions. }\end{array}$ & X39 \\
\hline 2 & Accounting and auditing standards are applied & $\mathrm{X40}$ \\
\hline & International & $\mathbf{X 4 1}$ \\
\hline & Iraqi & X42 \\
\hline & $\begin{array}{l}\text { International after adapting it in a way that is consistent with the requirements of } \\
\text { the Iraqi environment in private banks. }\end{array}$ & X43 \\
\hline 3 & $\begin{array}{l}\text { Existence of laws and legislations clarifying the rights and duties of shareholders } \\
\text { such as the right to vote, the election of members of the Board of Directors, the } \\
\text { right to appointment and the dismissal of external auditors in the private bank }\end{array}$ & X44 \\
\hline 4 & $\begin{array}{l}\text { There is a written description of the terms of reference of the audit committee (if it } \\
\text { exists within your company) and other committees of the board of directors in } \\
\text { private banks and in compliance with laws and regulations. }\end{array}$ & X45 \\
\hline 5 & $\begin{array}{l}\text { In the event that the director performs the duties assigned to him, he is guided by } \\
\text { the spirit of the law along with the rules of professional conduct. }\end{array}$ & X46 \\
\hline 6 & $\begin{array}{l}\text { The administration reviews laws and legislations, and requires it to be updated at } \\
\text { least once every three years. }\end{array}$ & $\mathrm{X} 47$ \\
\hline
\end{tabular}

According to the global analysis shows after analysis of the links variables through the basal values shown in Table No. (8) There are three main factors affecting the degree of use by the bank on the laws and regulations represent grassroots values that are greater 
than one and ranked according to the importance of the impact of each factor on Institutional control.

Table No. (8)

Basal values and contrast ratio factor of the total variation

\begin{tabular}{|c|c|c|c|}
\hline Factor & $\begin{array}{c}\text { baseline } \\
\text { values }\end{array}$ & $\begin{array}{c}\text { contrast } \\
\text { ratio }\end{array}$ & $\begin{array}{c}\text { Society } \\
\text { variation }\end{array}$ \\
\hline 1 & 2.602 & 32.527 & 32.527 \\
\hline 2 & 1.793 & 22.408 & 54.935 \\
\hline 3 & 1.373 & 17.163 & 72.098 \\
\hline 4 & .797 & 9.967 & 82.065 \\
\hline 5 & .572 & 7.156 & 89.221 \\
\hline 6 & .397 & 4.957 & 94.178 \\
\hline 7 & .275 & 3.432 & 97.610 \\
\hline 8 & .191 & 2.390 & 100.000 \\
\hline
\end{tabular}

This factor constitutes a great and distinct importance in influencing laws and legislations, as $32.527 \%$ of the total variance indicates, so the main factor for the interpretation of the correlation matrix is that the two variables $(\mathrm{x} 60, \mathrm{x} 58)$ included the first order of importance Question No. (2) Paragraph (c) which is International accounting and auditing standards are applied after adapting them in a way that is consistent with the requirements of the Iraqi environment in private financial banks, and then came second in terms of importance Question No. (4) represented by there is a written description of the terms of reference of the audit committee (in case it is within your company) and other committees of the Council Management in private banks In compliance with laws and regulations.

As for the analysis of the second factor, where it comes in the second degree of importance in explaining the relationship between the variables, as it explains $22.408 \%$ of the total variance, it was represented by the two variables (x55, x59). The significance is in this factor, where question No. (3) came first, which is the presence of laws and legislations that clarify the rights of shareholders. And their duties such as the right to vote, the election of members of the Board of Directors, the right to appoint and dismiss external 
auditors in private banks, and then question No. (1) at the second level, which is, the Board of Directors has a clear policy to monitor the bank's full compliance with laws, regulations and instructions.

As for the third factor, which comes in the third degree of importance in explaining the relationship between the variables, as it explains $17.163 \%$ of the total variance, it was represented by the two variables (x57, x56), which was represented by question No. (2) represented by the application of accounting and auditing standards, where paragraph (a) came first from Where the importance, which was represented by the international and the other Iraqi paragraph.

Through observing the answer to the questionnaire questions, it was found that the majority of banks are interested in applying the laws, legislations and instructions issued by the bank itself and issued by the Central Bank and the Office of Financial Supervision to protect the rights of shareholders and related parties such as depositors, represented by international standards after adapting them in a manner that is consistent with the requirements of the Iraqi environment.

As for efficient and appropriate internal regulations and legislation and issuing internal instructions to the bank, a selection process is made to determine its various tasks, devices and powers, which in turn ensure the achievement of administrative and financial oversight of its business and this thus leads to the completion of all work efficiently and effectively.

For the purpose of indicating the extent of each bank's agreement with the results of the global analysis of the matrix of factors recycled for the first and second factors of a paragraph (laws and legislations), the researcher used the percentage method and the table that illustrates this.

Through the answers received for the first axis, he notes the desire of the Iraqi private banks to apply the foundations and principles of institutional control because of their fundamental role in organizing businesses and raising their level with the level of global banking business and thus increasing their activities and expanding their business and increasing their profits and finally maintaining the continuity of banks and adding value to shareholders and stakeholders.

\section{Conclusion:}

Institutional control is a control system adopted by financial business establishments to distribute powers and responsibilities between the different parties involved in it and to establish rules and procedures related to their affairs, and because of the emergence of fraudulent financial reports in major international companies and cases of bribes and fraud 
the need arises for the need to have an institutional control system for the purpose of improving the company's performance through a process Improving risk management and the availability of adequate control systems to reduce risks and add value to them in order to differentiate the company from its competitors in the market and maintain its economic reputation when making decisions to serve shareholders and owners A solution and society in general, and to achieve justice for all relevant parties, which entails the protection of their interests, and this requires the necessity of providing appropriate information about the company's activity and the speed of its delivery to those dealing with it. The company on the other hand, such as disclosure, transparency, accountability, responsibility, justice, independence, laws and legislations that are launched from within the company in directing its business to meet the needs of shareholders, investors and those with a relationship with the company.

On the other hand, recent technological advances affect the improvement and provision of services and information about institutional control activities and the possibility of using it to exchange ideas and spread information between many countries, and this affects the increase in the effectiveness of institutional control as well as publishing reports via the Internet that achieves effective participation in making decisions about The main changes of the company, provided that the shareholder has the right and freedom to access the appropriate and timely information, The researcher recommends reviewing the current practices in the tasks of the internal and external accounting and auditing sectors related to accounting disclosure, transparency, responsibility, accountability, justice, independence, laws and legislations in each bank as an essential input for developing control systems in their accounting and administrative dimensions, and that is guided by the principles of institutional control announced in support of the performance of these banks to achieve The best use of the resources of these economic activities, provided that the relationship that links, organizes and does the performance of the external auditor's tasks is determined and its relationship to the internal auditor is documented taking into account relevant international standards Where these tasks become:

1- A job with an added value for a bank rather than an administrative cell for the extent of the legitimacy of operations.

2- A continuous service that provides management and stakeholders with the means to confirm and consult the side of financial and administrative examination.

3- Take advantage of the results to be the cornerstone in the implementation of the risk management tasks that seek to be a means of protection, accuracy, commitment and sufficiency.

\section{Reference:}


1. Japan Committee, Corporate Governance Forum, Japan Corporate Governance Committee, Revised Corporate Governance Principles, Oct.2001

2. Hermanson, Dana R.( Kennesaw State University) \& Rittenberg ,Larry E,University of Wisconsin-Madison, "Internal Audit and Organizational Governance "The Institute of Internal Auditors Research Foundation, Copyright (C) 2003 by The Institute of Internal Auditors, 247 Maitland Avenue, Altamonte Springs, Florida 32701-4201.

3. Jane, F. Mutchler (Georgia State University) "Independence and Objectivity : A Framework For Research Opportunities in Internal Auditing ",Georgia State University, The Institute of Internal Auditors Research Foundation Copyright $(2003$ by The Institute of Internal Auditors, 247 Maitland Avenue, Altamonte Springs, Florida 32701-4201

4. Lindow, P.E, and Race, J.D. "Beyond Traditional Audit Techniques," Journal of Accountancy, 194, July 2002

5. Elisabeth, B. Dedman, Cadbury Committee, Recommendations on Corporate Governance - A Review of Compliance and Performance Impacts, University of Liverpool, International Journal of Management Reviews, Vol.4,PP335-352,Dec. 2002.

6. Roth, James PhD, CIA, CCSA, and Espersen, Donald CIA, CBA. . PRO STAFF Finance Accounting, Audit Committee Charter Issues Matrix, Internal Auditor's Role in Corporate Governance, Internal Auditor's Role in Corporate Governance, Published by The IIA Research Foundation issues January 29, 2003

7. Tone at the Top, New Governance Rules Require Internal Auditing, Published By the Institute of Internal Auditors, Issue 21, Feb, 2004

8. William R. Kinney, Jr.( University of Texas-Austin ) "Auditing Risk Assessment and Risk Management Processes "The Institute of Internal Auditors Research Foundation Copyright (C) 2003 by The Institute of Internal Auditors, 247 Maitland Avenue, Altamonte Springs, Florida 32701-4201.

9. Church, B.K., J.J. McMillan, and A. Schneider, "Factors Affecting Internal Auditors' Consideration of Fraudulent Financial Reporting During Analytical Procedures," Auditing: A Journal of Practice \& Theory, March 2001, pp. 65-80

10. AICPA, American Institute of Certified Public Accountants, How the Sarbanes-Oxley Act of 2002 Impacts the Accounting Profession, August 9, 2003

11. Basell, Enhancing corporate Governance in Banking Organization, 1999 
له زيزّ روناكى ثنم بابةتهنه

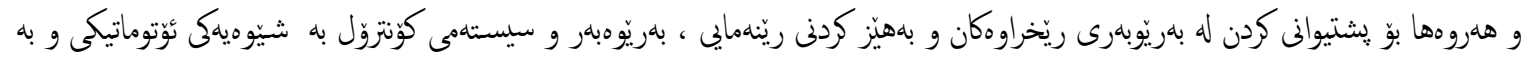

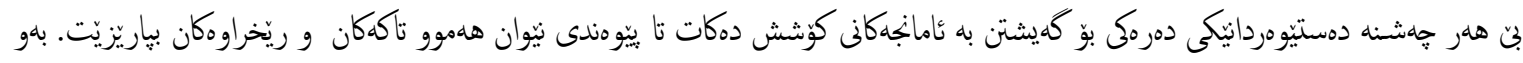

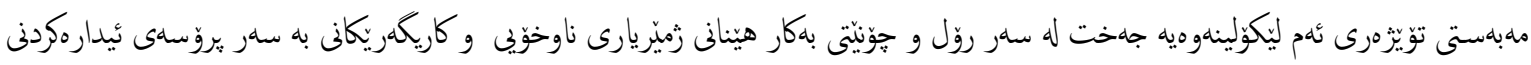

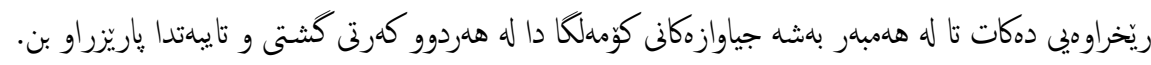

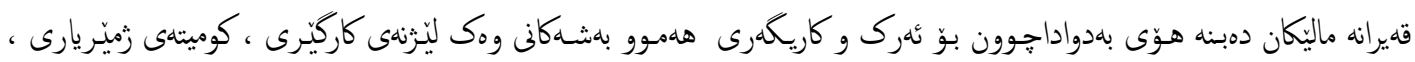

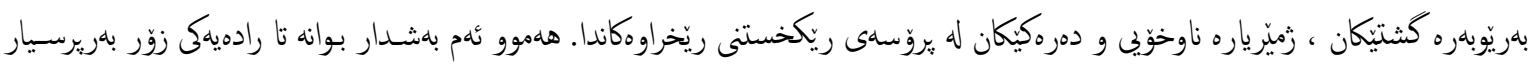

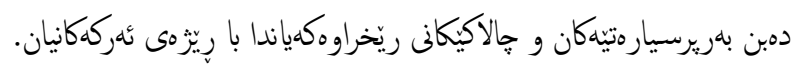

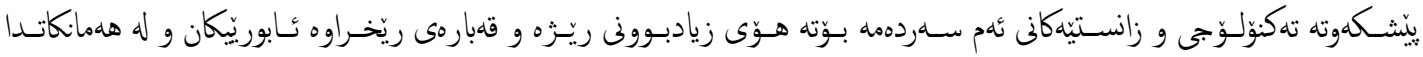

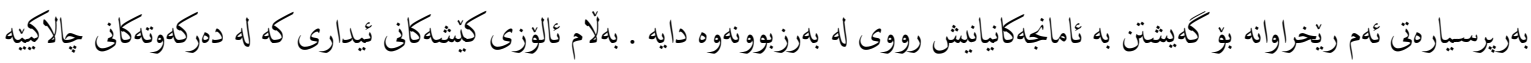

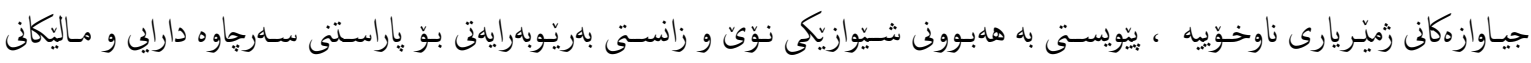

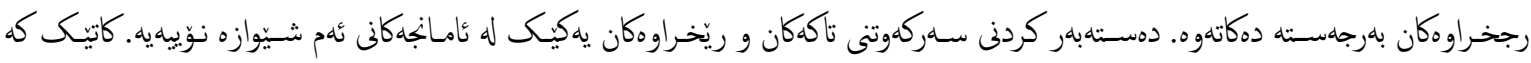

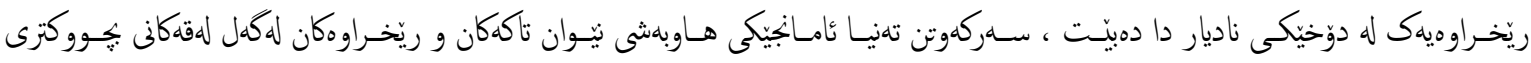
سيستنمهك هلثمار دمكيّت.

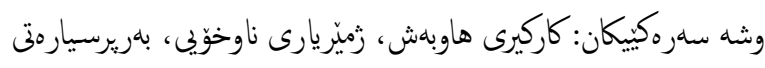

الملخص:

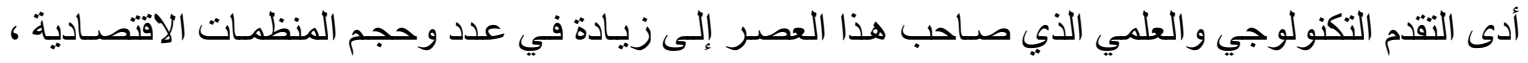

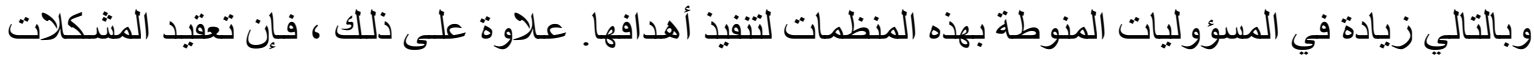

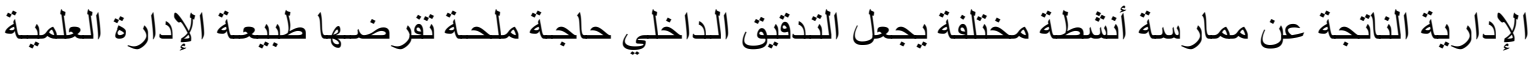

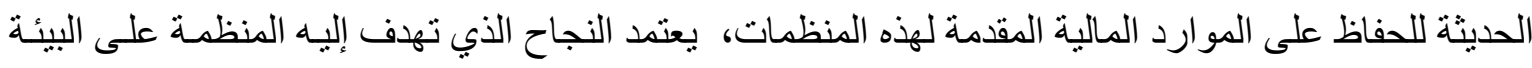

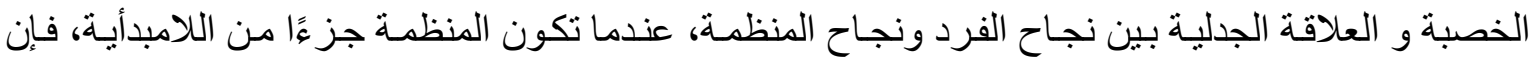

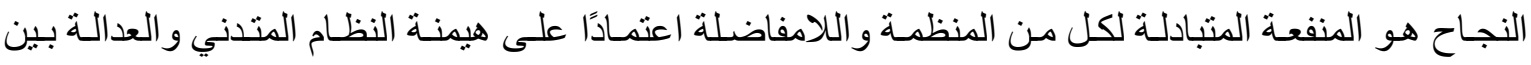

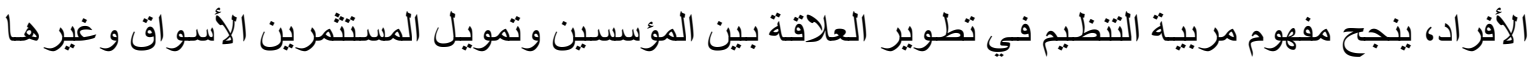

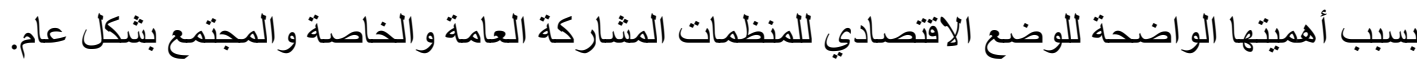

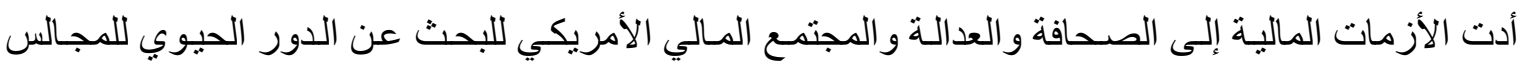

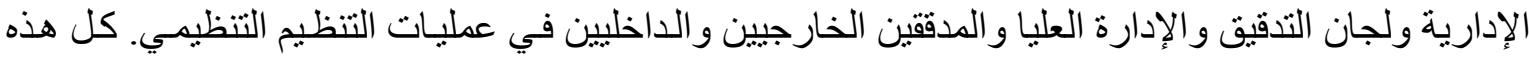

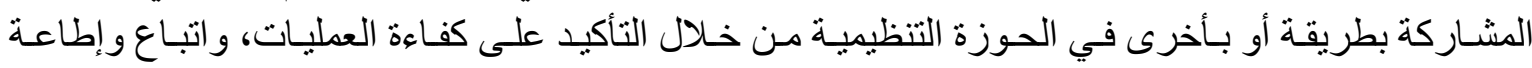

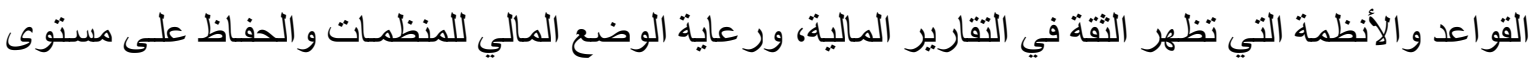
مقبول من المخاطر إذا كانت تفي بواجباتها بشكل صحيح. 


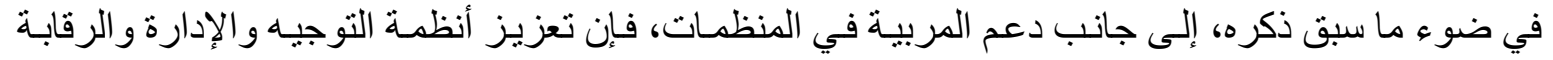

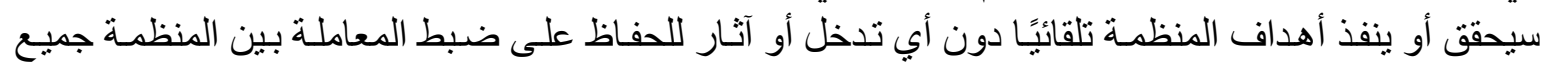

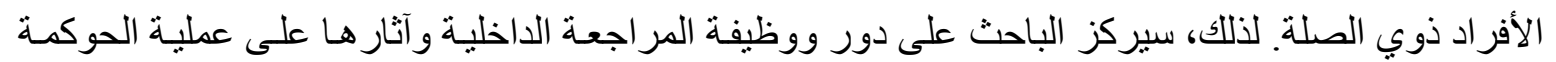
التنظيمية بهدف دعمها استجابةً لمصالح مختلف الأطر اف في المجتمع ، القطاعين العام و الخاص. 